\title{
Studi Lingkungan Desa Pentingsari Kabupaten Sleman Sebagai Sumber Pembelajaran IPS SD
}

\author{
Ikhlas Suryawati ${ }^{1}{ }^{*}$, Lia Aliatul Ilmi ${ }^{2}$, Savira Ningrum ${ }^{3}$, Setia ${ }^{4}$ \\ 1)23)4)Program Studi PGSD Universitas Gunung Jati Cirebon; Jl. Terusan Pemuda No.32, \\ Cirebon; ikhlassrywt28@gmail.com
}

\begin{abstract}
Abstrak. Studi Lingkungan ini bertujuan untuk menggali, mengkaji, dan mendeskripsikan pengetahuan sosial yang ada pada suatu daerah yang dapat dijadikan suatu sumber pembelajaran IPS yang menarik kepada peserta didik. Studi lingkungan ini menggunakan pendekatan kualitatif. Studi lingkungan ini dilakukan di Desa Wisata yaitu Desa Pentingsari Sleman Yogyakarta, dengan subjek Masyarakat Setempat dan Kondisi sosialnya. Dalam studi lingkungan ini kami mengumpulkan data melalui Wawancara, Observasi, dan Dokumentasi. Hasil studi lingkungan ini menunjukan bahwasannya kebudayaan-kebudayaan dan kebiasaan sosial masyarakat dapat dijadikan sumber pembelajaran IPS yakni dari segi : (1) Sejarah desa pentingsari, (2) Kondisi Geografis desa pentingsari, (3) Kondisi Demografi desa pentingsari.
\end{abstract}

Kata Kunci. Studi Lingkungan, Ilmu Pengetahuan Sosial, Desa Pentingsari

Abstract : This study environmental study aims to multiply, examine and describe the social knowledge that exists in an area that can be used as an interesting source of IPS learning to students. this environmental study uses a qualitative approach. this environmental study was conducted in pentingsari tourist village sleman yogjakarta with the subject of local people and their social conditions. In this environmental study we collected data through interviews, observation and documentation. The results of this environmental study show that the culture and social habits of the community can be used as sources of learning,terms of : (1) village history pentingsar, (2) Geographical conditions of the village pentingsari, (3) village demograpihic conditions pentingsari.

Keywords. Environmental Studies, Social Sciences, Pentingsari Village

\section{Pendahuluan}

Menurut Rudy Gunawan menyatakan bahwa: “ IPS merupakan salah satu mata pelajaran yang diberikan di SD yang mengkaji seperangkat peristiwa, fakta, konsep, dan generalisasi yang berkaitan dengan isu sosial." Ilmu pengetahuan sosial sebagai mata pelajaran tidak semata membekali ilmu saja 
lebih dari itu membekali juga sikap atau nilai dan keterampilan dalam hidup bermasyarakat sehingga mereka mengetahui benar lingkungan, masyarakat, dan bangsanya dengan berbagai karakteristiknya. Selain itu Rudy Gunawan menyatakan bahwa pembelajaran Ilmu Pengetahuan Sosial (IPS) di SD hendaknya memperhatikan kebutuhan anak yang berusia antara 6-12 tahun. Anak dalam kelompok usia 7-11tahun menurut Piaget (1963) berada dalam perkembangan kemampuan intelektual/kognitifnya pada tingkat konkret operasional. Mereka memandang dunia dalam keseluruhan yang utuh, dan mengaggap tahun yang akan datang sebagai waktu yang masih jauh. Yang mereka pedulikan adalah sekaramg (konkrit), dan bukan masa depan yang belum bisa mereka pahami (abstrak).

Dapat disimpulkan bahwa pembelajaran di IPS SD mengkaji seperangkat peristiwa, fakta, konsep, dan generalisasi yang berkaitan dengan isu sosial, memuat materi geografi, sejarah, sosiologi, dan ekonomi. Sistem pembelajaranya menelaah dan mengkaji gejala atau masalah sosial dan berbagai aspek kehidupan sosial, serta pelajaran IPS dirancang untuk mengembangkan pengetahuan, pemahaman, dan kemampuan analisis terhadap kondisi sosial masyarakat dalam memasuki kehidupan bermusyawarah yang dinamis.Desa Pentingsari sendiri merupakan desa kecil yang masih mempertahankan ketradisionalanya dan masih mempertahankan keaslian kehidupan sederhanya itu sendiri.

\section{Metode Penelitian}

Dalam studi lingkungan ini dilakukan untuk memperoleh data mengenai "Sumber belajar Ilmu Pengetahuan Sosial SD dari Desa Wisata Pentingsari Sleman Yogyakarta". Teknik dalam pengumpulan data studi lingkungan ini yang digunakan yaitu dengan cara melakukan Wawancara, Observasi, dan Dokumentasi. Pada penelitian ini menggunakan cara wawancara langsung dengan tokoh masyarakat dan mengajukan pertanyaan-pertanyaan terstuktur yang disusun dari pedoman wawancara yang sistematis serta dapat dikembangkan sesuai dengan situasi dan kondisi dilapangan untuk mengumpulkan data yang dicari, selain itu penelitian ini menggunakan teknik 
observasi dengan mendatangi tempat-tempat atau balai pertemuan yang ada di desa pentingsari tersebut. Adapun penelitian ini juga menggunakan teknik pengumpulan data berupa dokumen-dokumen untuk memperkuat penelitian bisa berupa foto, video, perekam suara, dan media internet serta catatan lapangan.

\section{Hasil dan Pembahasan}

\section{A. Lingkungan Sosial Desa PentingSari}

Desa Wisata adalah salah satu program dari pemerintah. Padatahun 2006 pemerintah meluncurkan program yang bernama PariwisataInti Rakyat, Pariwisata Inti Rakyat yaitu program pariwisata yangberdasarkan pemberdayaan masyarakat. Pada perkembangan selanjutnyadidirikan program yang bernama Desa Wisata, jadi masyarakatberkesempatan untuk menjadikan desanya menjadi desa wisata denganketentuan-ketentuan tertentu. Pemerintah memberikan kesempatan padamasyarakat untuk berpartisipasi di bidang pariwisata karena pariwisatadapat memberikan kesejahteraan bagi rakyat. Desa Wisata yang munculpertama adalah Desa Wisata yang berada di Jawa tengah di daerahPurbalingga, lalu mulai berkembang di Yogyakarta salah satunya DesaWisata Pentingsari yang muncul pada tahun 2008 disamping itu adabanyak Desa Wisata, yang sekarang jumlahnya ada 37 Desa Wisata Kabupaten Sleman.

Desa Wisata Pentingsari dirintis pada awal tahun 2008 sesuaidengan niat dan kesepakatan warga masyarakat setelah melihat dan mengamati beberapa desa wisata lain yang sudah berdiri sebelumnya,kemudian tokoh masyarakat berkumpul untuk membicarakan hal tersebut,selanjutnya semua masyarakat dikumpulkan untuk diajak bermusyawarahdan sosialisasi mengenai rencana Desa Pentingsari akan dijadikan DesaWisata, dan akhirnya semua masyarakat sepakat. Pada bulan Maret 2008masyarakat dan tokoh masyarakat membuat proposal yang diajukan keDinas Pariwisata Sleman. Pada tangal 1 April pihak dari Dinas PariwisataSleman mensurvey Desa Pentingsari untuk melihat kelayakannya menjadiDesa Wisata. 
Akhirnya Pemerintah Kabupaten Sleman mengkukuhkanDesa Pentingsari sebagai Desa Wisata pada tanggal 15 April 2008.Pada bulan Juni 2008 Desa Wisata Pentingsari mengikuti festivalDesa Wisata se Kabupaten Sleman dan berhasil menjadi juara II (kedua),kemudian pada bulan November 2009 Desa Wisata Pentingsari mengikutilomba Desa Wisata se-Propinsi Daerah Istimewa Yogyakarta dan berhasilmenjadi juara I (pertama) serta mendapat penghargaan sebagai DesaWisata dengan keunikan alam.

\section{B. Kondisi Geografis Desa Pentingsari}

Dusun Pentingsari terletak di Kelurahan Umbulharjo, Kecamatan Cangkringan Kabupaten Sleman,Daerah Istimewa Yogyakarta. Dusun Pentingsari merupakan salah satu dusun yang terletak di kawasan yang berdekatan dengan lereng gunung merapi dan terletak di lereng obyek wisata Kali Adem sebelum Lapangan Golf Merapi (Merapi Golf) yang berhawa sejuk dan temasuk ke dalam pengembangan pariwisata Lereng gunung merapi. Desa Wisata Pentingsari (Dewi Peri) berada di ketinggian $\pm 600 \mathrm{~m}$ dpl dan berada pada jarak 12,5 di puncak Gunung Merapi serta berjarak sekitar $22 \mathrm{~km}$ dari pusat kota Yogyakarta (45 menit perjalanan). Kondisi lingkungan berupa alam pedesaan berkontur bukit dan dataran rendah yang diapit 2 sungai (Sungai Kuning dan Sungai Pawon) yang berhulu di lereng Gunung Merapi. Wilayah Dewi Peri terdiri dari areal pemukiman, perkebunan, hutan rakyat, pertanian (padi dan sayur) serta Daerah Aliran Sungai (DAS) Sungai Kuning dan Pawon.

Adapun batas wilayah Dusun Pentingsari yakni dari sebelah Utara yaitu Dusun Gambertan, sebelah Selatan yaitu Dusun Bedoyo, sebelah Timur yaitu Dusun Gatak Cancangan, dan yang terkahir sebelah Barat yaitu Dusun samba.

Adapun Luas Wilayah Dusun Pentingsari adalah seluas 103 hektar yang terdiri atas Tanah pekarangan seluas 25 hektar, Tanah tegal seluas 39 hektar, Tanah sawah seluas 23 hektar, Sawah Pertanian seluas 3 hektar, Tegalan seluas 10 hektar, Industry seluas 1 hektar, Perkebun seluas 16,8 hektar, Permukiman seluas 5,8 hektar dan untuk yang lainnya seluas 7,4 hektar.

\section{Kondisi Demografi Desa Pentingsari}

Dusun Pentingsari terbagi atas 2 RW dan 4 RT dengan jumlah total penduduk 399 penduduk dengan jumlah Kepala Keluarga 122 , jumlah laki-laki 
162 jiwa dan jumlah penduduk perempuan 177 jiwa. Mata pencaharian penduduk Dusun Pentingsari yang dominan adalah petani namun ada juga yang menjadi Pegawai Swasta, Pegawai Negri Sipil. Kepadatan penduduk 3,6 jiwa/ha.

Fenomena Sosial yang dapat dijadikan sebagai Sumber Belajar IPS SD

\section{Sejarah Desa PentingSari}

Didalam sejarah desa pentingsari untuk dijadikan pembelajaran anak disekolah dasar dalam mata pelajaran IPS anak-anak dapat mengetahui pengertian sejarah ituh apa dengan mengetahui ciri-ciri sejarah seperti yang ada pada desa pentingsari yang dapat dijadikan pembelajaran yang menarik untuk anak-anak sekolah dasar contohnya seperti asal-usul berdirinya desa pentingsari dan lain-lain.

\section{Kondisi Geografis Desa Pentingsari}

Didalah kondisi geografis desa pentingsari untuk dijadikan pembelajaran anak sekolah dasar dalam mata pelajaran IPS anak-anak dapat mengetahui geografis itu seperti apa dengan mengetahui ciri-ciri geografis itu seperti apa contohnya batas-batas wilayah dan luas wilayah yang ada didesa pentingsari.

\section{Kondisi Demografi Desa Pentingsari}

Didalam kondisi demografi desa pentingsari untuk dijadikan pembelajaran anak sekolah dasar dalam mata pelajaran IPS anak-abak dapat mengetahui demografi itu seperti dengan mengetahui ciri-ciri geografi itu seperti apa contohnya organisasi-organisasi masyarakat, jumlah penduduk, dan lain-lain yang dapat dijadikan pembelajaran disekolah.

Matriks fenomena sosial yang ada didesa pentingsari sebagai sumber belajar

Tabel 1.

No Fenomena Sosial Deskripsi

1. Sejarah

Mengetahui pengertian itu apa dengan
( IPS)

Mengenal makna peninggalan-peninggalan sejarah sejarah yang yang ada di indonesia. 
mengetahui ciri-ciri

sejarah yaitu asal-

usul

Desa

Pentingsari, tempattempat bersejarah di

Pentingsari.

2. Kondisi Sosial (IPS)

Ekonomi

Beragam

pencaharian

Pentingsari

kondisi

pemanfaatan

alamnya untuk

meningkatkan mutu

finansial warga desa

Pentingsari

3. Kondisi Geografi

Memiliki sumber

3.3. Mengidentifikasi keadaan sumber daya daya alam yang alam

melimpah

dikarenakan letak

Desa Pentingsari dalam letak geografisnya.

geografis desa

Pentingsari terletak

di dataran tinggi

sehingga memiliki

Menganalisis peran ekonomi dalam upaya mata menyejahterakan kehidupan masyarakat di warga bidang sosial dan budaya untuk memperkuat kesatuan dan persatuan bangsa Indonesia serta hubunganya dengan karakteristik ruang.

(IPS) (reng.

.


tanah yang subur.

4 Jenis-Jenis pekerjaan (IPS)

Berbagai pekerjaan 4.3 menyajikan hasil identifikasi kegiatan yang ada di dalam ekonomi daam meningkatkan kehidupan desa Pentingsari. masyarakat di bidang pekerjaan, sosial, dan budaya di lingkungan sekitar sampai Provinsi.

\section{Simpulan}

\section{Sejarah Desa Pentingsari}

Dalam sejarah banyak mengambil pembelajaran mengenai masa sesudah dan sebelum terjadinya erupsi Gunung Merapi yang sangat dahsyat kala itu. Masyarakat yang berada diluar daerah Yogyakarta mulai mengenal desa pentingsari sebagai desa wisata sekaligus desa pembelajaran untuk digali peninggalan-peninggalan yang masih bisa dijadikan sebagai pembelajaran IPS disekolah dasar.

\section{Kondisi Geografis}

Dalam kondisi geografis didesa pentingsari terletak didataran tinggi dimana desa pentingsari memiliki kondisi geografis yang memiliki banyak pohon yang rindang dimana curah hujan didaerah tersebut sangat tinggi. Kondisi geografis ini pun menjadikan pembelajaran IPS yang mempelajari letak dan batas-batas wilayang yang terjadi didesa tersebut.

\section{Kondisi Demografis}

Dalam kondisi demografis yang ada didesa pentingsari ini menjadikan contoh terhadap desa-desa yang ada dikarenakan didalam desa pentingsari ini tumbuhnya rasa kebersamaan yang sangat melekat yang terdapat banyak organisasi-organisasi masyarakat. Yang dapat menjadikan kondisi demografis ini pun menjadi pembelajaran IPS disekolah dasar yang mengajarkan peserta 
didik berorganisasi antara peserta didik satu dengan peserta didik lainnya dengan baik.

Berdasarkan uraian diatas dapat disimpulkan bahwasannya pembelajaran IPS disekolah dasar dapat diambil dari manapun contohnya seperti desa wisata pentingsari yang dapat dijadikan sumber belajar IPS SD oleh anak-anak yang meliputi sejarah desa pentingsari, kondisi geografis desa pentingsari, dan kondisi demografis desa pentingsari. Oleh karena itu selain dari buku atau sumber belajar tertulis yang lainnya kita juga dapat melihat langsung sejarah itu apa, geografis itu seperti apa, dan demografis itu bagaimana, yang peserta didik pun dapat berfikir lebih konkret dengan melihat secara langsung kenyataannya melalui desa wisata pentingsari ini.

\section{Daftar Pustaka}

Gazalba, S. (1966). Pengantar Sejarah Sebagai Ilmu. Jakarta: Bharata

Irwanto, D dan Syair, A. (2008). Isi Metodologi dan Historigrafi Sejarah. Yogyakarta: Bentang Budaya

Murtianto, H. (2008). Modul Belajar Geografi. Bandung: Universitas Pendidikan Indonesia

Rasyid, AR H. (2016). Impelentasi Pendidikan Karakter Dalam Pembelajaran IPS di Madrasah Aliyah. Yogyakarta: Sosial Jurnal Ilmu-Ilmu Sosial

Subadi, T. (2008). Sosiologi. Surakarta: Universitas Muhammadiyah Surakarta Wulansari, D. (2009). Sosiologi Konsep dan Teori. Bandung: Pt. Refika Aditama 